\title{
Weak Point Analysis and Work Design for Positioning Measures of Patients in Need of Intensive Care
}

\author{
Landau $\mathrm{K}^{1 *}$ and Jacobs $\mathbf{M}^{2}$ \\ ${ }^{1}$ Institute for Organization and Work Design, Austria \\ ${ }^{2}$ Bavaria Clinic, Germany
}

*Corresponding author: Kurt Landau, Institute for Organization and Work Design, Lechnerschaft 110, 9872 Millstatt, Austria, Tel: +43/676-928 22 78; Email: office@ioa-online. at

\section{Abstract}

Working on and with the sick or elderly person has various health effects on the nursing staff. The relevant literature describes the wide range of musculoskeletal disorders, infections, skin diseases or burnout. A high musculoskeletal load on the nursing staff results mainly from transfer and positioning measures on the patient. In this paper we deal with work process analysis and workplace design for positioning measures. Video analyses of the manual work performed by nursing staff on patients requiring the most intensive care were carried out at 71 workplaces in ward rooms and stress factors were calculated using the REBA method. The causes of high levels of stress are identified and ergonomic recommendations for improving working methods are derived.

Keywords: Ergonomic Workload Analysis of Nursing Staff; Patients in Need of Intensive Care; Weak Points; Positioning Measures; Reba-Procedure

\section{Introduction}

Changes of position in the patient's bed are everyday tasks of the nursing staff; they are necessary for health reasons and for comfort aspects, especially if the sick or elderly person can only move around to a limited extent. Positioning measures serve to relieve pressure or ease breathing. They can relieve pain or support further therapeutic measures.

The word "positioning measure" assumes a passive role of the patient. However, it is important to rely on the patient's assistance whenever possible - as far as the patient's health permits. Positioning as an activating care measure is described in a number of relevant publications, for example from a kinaesthetic point of view, from the point of view of the Bobath concept and basal stimulation [1,2]. Many of these publications are aimed at changing the way nurses work, but rarely at ergonomic workplace and work process design. There is also a lack of a holistic approach related to the work system. The well-being of the patient is paramount; there is a risk that the health protection of carers - especially with regard to musculoskeletal disorders - will be neglected. This paper therefore addresses these deficits and deals with the ergonomic aspects of manual work on and with the patient from an ergonomic perspective.

\section{State of Research}

Health statistics of nursing staff in many countries point to exceptional workload and extraordinary sickness rates $[3,4]$. The high level of absenteeism in the health care system is due both to an above-average incidence of illness and a longer duration of illness. Psychophysical stress on caregivers has been the subject of many studies in the past [5-9]. In the physical area, these include taking up forced positions, lifting and carrying or the use of force. This can regularly result in unfavourable postures, high disc compression, especially at the lumbo-sacral transition, but also stress in 
the shoulder-neck and knee joint areas. Exposure studies are available in the form of surveys, questionnaires or measurements. According to representative studies, more than $1 / 3$ of the nursing staff surveyed in Germany have to lift and carry heavy loads more than ten times a day. Almost one third of the employees lift or carry heavy loads 1-5 times per working shift or 6-10 times per shift, respectively [10]. The situation is similar in outpatient care, but there are no or hardly any lifts or small aids available for patient transfers. As a rule, outpatient nursing staff cannot count on support from colleagues for lifting and carrying. In several countries, some nursing staff illnesses are recognised as occupational diseases and can be compensated accordingly e.g. in Germany the disc-related diseases of the lumbar spine [11]. In intensive care, the stress caused by heavy lifting and carrying is in the foreground. In a meta-study of 27 articles, the results showed that in the $n=13,317$ reported cases, the prevalence of work-related musculoskeletal disorders among nurses was about $72 \%$ [6]. In a further meta-study, van Hoof and colleagues investigated the efficiency of various behavioural-ergonomic measures for the recovery of lumbar spine patients from nursing [12]. They came to a sobering conclusion that neither training for load handling nor stress management produced satisfactory results. Combined behavioural-ergonomic measures (e.g. stretching plus back exercise), on the other hand, produce better results. Passive physiotherapy came off worst. However, in this study, too, only behavioural-ergonomic measures were examined, not ergonomic design measures.

We therefore pursue the following objectives in this paper:

- For nursing activities with a high load on the musculoskeletal system, the weak points in work design and behavioural ergonomics should be identified,

- For a broad repertoire of positioning and transfer activities, quantitative exposure levels should be determined using a simple screening tool,

- Improvements to work processes should be proposed.
In addition to work design and the improvement of work processes, there is also the possibility of using strength training to prevent nursing staff from falling ill. Jacobs et al. comment on this [13].

\section{Method}

We have carried out video analyses and REBA calculations [14] in a clinic for rehabilitation and followup treatment at a total of 71 workplaces in ward rooms of patients requiring the most severe care (awake coma ward, patients after transplantations, paraplegics). The video analyses lasted between 10 and 50 minutes - depending on the severity of the illness and the psychological state of the patient. All preparatory and follow-up work on transfers and positioning measures was also recorded. Video analyses were only carried out if the patient and nursing staff agreed. The analyses were only used for ergonomic evaluations by the authors of this paper. At publications real photos were replaced by drawings (see below).

In this paper, we will mainly focus on the positioning processes. Transfers, e.g. between bed and wheelchair or bed and shower bed, are examined elsewhere [15].

The REBA method takes intoaccount a total of 9 characteristics for posture and use of force combined to a point value (Table 1) $[14]:$

- Posture of the upper body (tilted or twisted forward and/or sideways),

- Head position (tilted forward or backward, turned, tilted sideways),

- Leg position (both legs take over body weight, step position, straddle position),

- Position of the upper arm,

- Position of the forearm,

- Wrist deflection angle,

- Use your power,

- Coupling between hand and object,

- Nature of activities.

\begin{tabular}{|c|c|c|}
\hline REBA point value & Risk level & Action \\
\hline 1 & Negligible & No design measure required \\
\hline $2-3$ & Low & Possibly (occasionally) take design measures \\
\hline $4-7$ & Average & Design measures required \\
\hline $8-10$ & High & Design measures to be implemented soon \\
\hline $11-15$ & Very high & Implement design measures now \\
\hline
\end{tabular}

Table 1: REBA point values, risks for employees and indicated design measures [14].

There are many methods for assessing musculoskeletal load on an ordinal or metric scale (overview e.g. [16]). We have chosen REBA because this method has been shown in preliminary studies [17-19] to have the best understanding among the nursing staff concerned. The 3DSSP method [20] was also used for validation purposes. These results are shown in Landau K [15]. 


\section{Results}

Lateral positioning as an example (other transfer and positioning measures in Landau $K$ [15])
The following Table 2 shows the steps described from an ergonomic point of view for a sideways positioning measure.

\begin{tabular}{|c|c|c|c|}
\hline No. & Instruction of the career(s) & Exemplary Image & REBA-value \\
\hline 1 & $\begin{array}{l}\text { First bring the bed to working height! } \\
\text { The nurse stands in a step position close to the edge of the } \\
\text { bed at the height of the patient's shoulders. She grasps the } \\
\text { patient's front and back shoulders. } \\
\text { The nurse now takes up momentum by shifting her weight } \\
\text { back and forth to pull the patient towards her in this section } \\
\text { by shifting her weight backwards. }\end{array}$ & & 13 \\
\hline 2 & $\begin{array}{l}\text { The nurse continues with the same technique in the area of } \\
\text { the pelvis and legs, grasping the patient's upper and lower } \\
\text { legs. } \\
\text { If the patient lies too close to the edge of the bed on his or her } \\
\text { side before positioning, a positioning correction towards the } \\
\text { middle of the bed is required beforehand. }\end{array}$ & & 11 \\
\hline 3 & $\begin{array}{l}\text { The caregiver stands in a step position close to the edge of } \\
\text { the bed at the level of the patient's pelvis. } \\
\text { The nurse turns the pelvis slightly upwards with the } \\
\text { dominant hand and pushes the other hand including forearm } \\
\text { in supination position under the patient's pelvis until the } \\
\text { entire pelvis rests on the hand and forearm. }\end{array}$ & & 11 \\
\hline 4 & $\begin{array}{l}\text { The caregiver pulls the patient towards him/her with his/her } \\
\text { lower arm by shifting his/her weight backwards. }\end{array}$ & & 12 \\
\hline
\end{tabular}




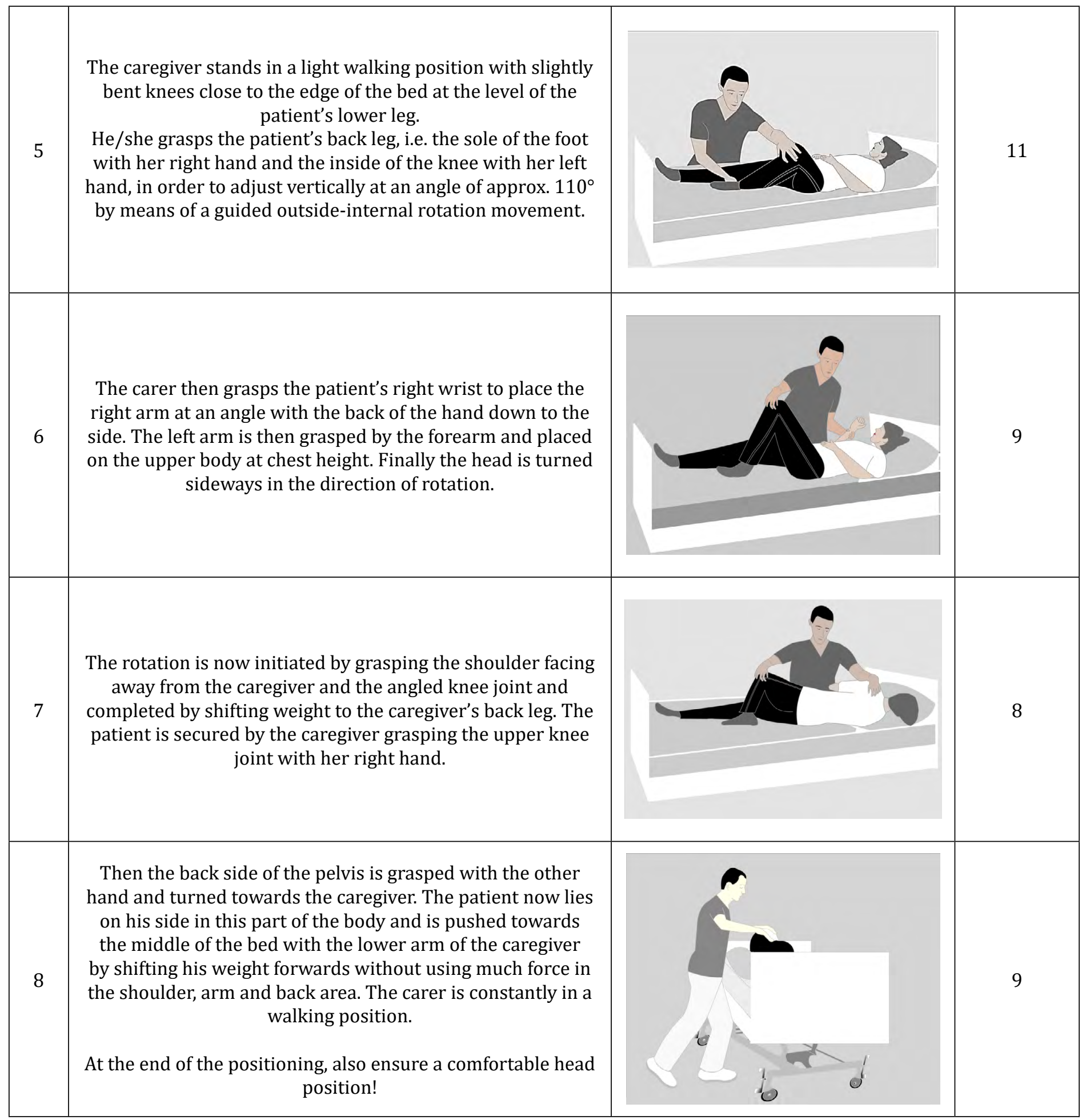

Table 2: Lateral positioning.

The mean value of the REBA analysis for this procedure is 10.5 , and the postures during the pulling of the patient and the rotation of the pelvis are rated with 13 and 12 points respectively. These high point values require immediate work design.

Table 3 shows the REBA arithmetic mean values for all positioning measures investigated by us: 


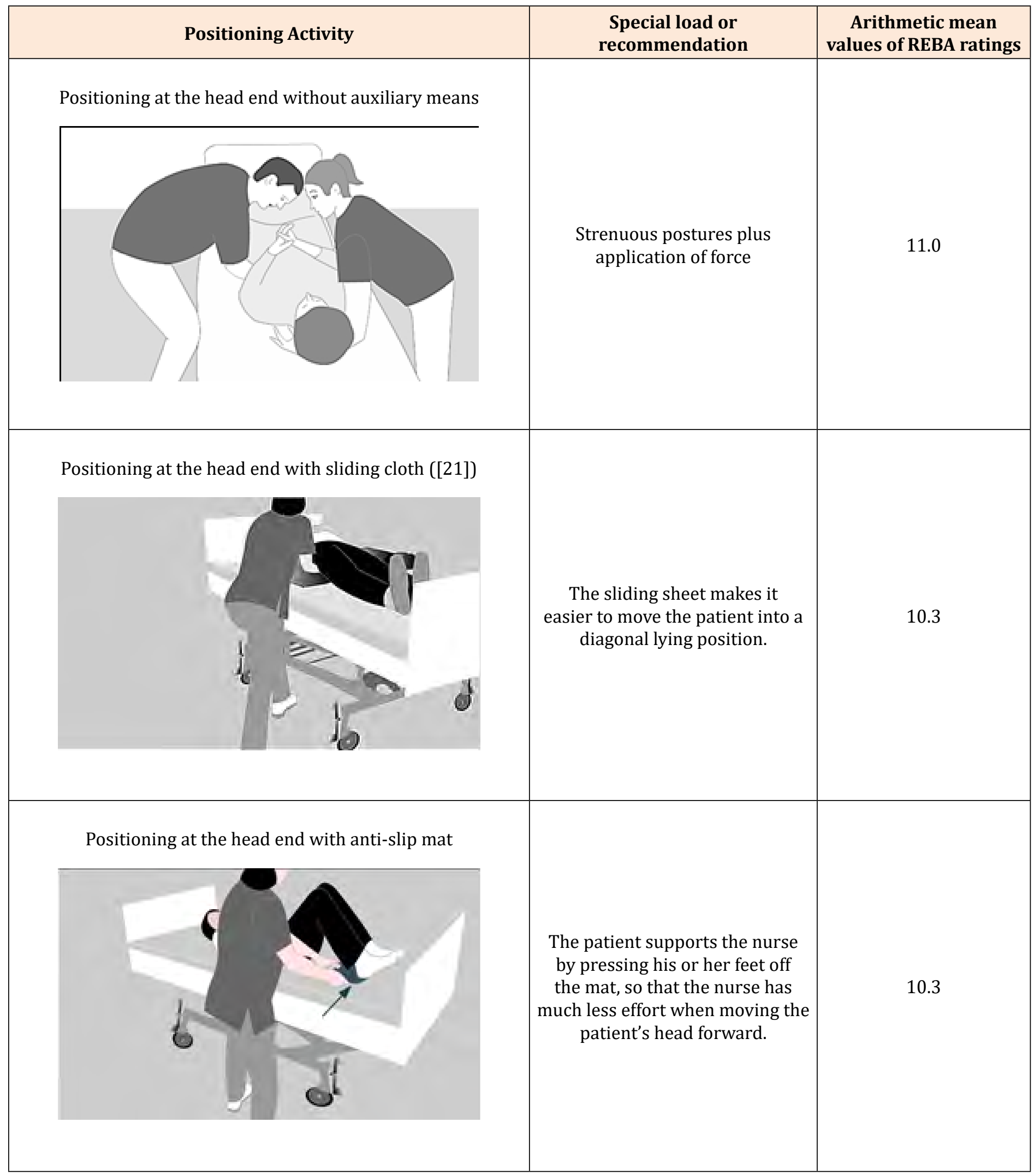




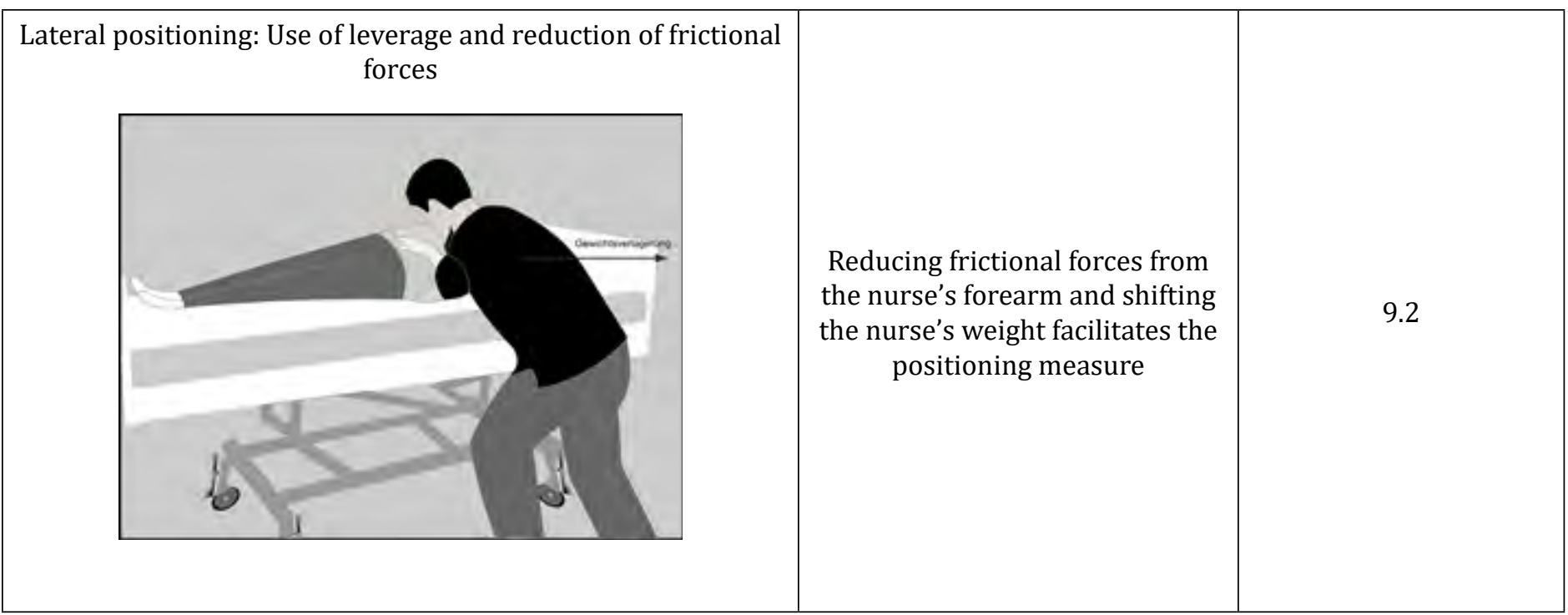

Table 3: Summarized REBA results.

The further positioning procedures are described and visualized in Landau $K$ [15]. The transfer measures not discussed in this paper ([15]) result in a mean REBA point value of 10.3 (range 8.4-13.0) if they are carried out alone and 7.1 (range 2.5-11.8) if they are carried out in pairs. From the point of view of musculoskeletal strain on the nursing staff, it is therefore advisable to carry out transfers and positioning in pairs. Alternatively, a patient lift should be used for transfers carried out alone.

As with many summary assessment methods, differences in the load on individual body regions are no longer visible in the REBA total score. Here is an example: An abducted upper arm increases the total score by " 1 ", if the lower and upper thigh are no longer bent strongly at the same time, this lowers the total score by "1", i.e. the overall result remains the same although the load on individual body regions has changed.

\section{Discussion}

The following guidelines (Table 4) focus on the improvement of (bio-)mechanical working conditions and the control (and, if necessary, reduction) of action forces and action moments. Recommendations are given for both positioning and transfers. The structure of the guidelines is based on the model of the work system [22].

\begin{tabular}{|c|c|c|c|}
\hline No. & $\begin{array}{c}\text { Related to } \\
\text { patients }\end{array}$ & Design principle & Remarks \\
\hline 1 & Basic suggestions & $\begin{array}{c}\text { Encourage patient to assist with transfer (T) and } \\
\text { positioning (P) }\end{array}$ & $\begin{array}{c}\text { As far as the clinical picture and current } \\
\text { condition allow }\end{array}$ \\
\hline 2 & & $\begin{array}{c}\text { Consider symptoms and diagnoses before and } \\
\text { during T \& P }\end{array}$ & \\
\hline 3 & & $\begin{array}{c}\text { Always inform patient in advance about transfer } \\
\text { and positioning measures }\end{array}$ & \\
\hline 4 & Details & Patient pull rather than lift & $\begin{array}{c}\text { Pulling is better than pushing, lifting } \\
\text { should be avoided if possible. }\end{array}$ \\
\hline
\end{tabular}




\begin{tabular}{|c|c|c|c|}
\hline 5 & Making patient „compact“ & $\begin{array}{c}|2| \\
\text { By positioning both legs or lower support } \\
\text { with knee joint roll and by crossing the } \\
\text { patient's arms on the chest, the load to be } \\
\text { moved by caregiver is concentrated over } \\
\text { a shorter distance; less attention must be } \\
\text { paid to leg and arm placement. }\end{array}$ \\
\hline 6 & $\begin{array}{r}\text { Put on the patient's clothing either with the } \\
\text { legs bent in the lateral position or in the supine } \\
\text { position of the patient. }\end{array}$ & $\begin{array}{c}\text { If the pelvis is to be lifted alternatively, } \\
\text { two caregivers are required. }\end{array}$ \\
\hline
\end{tabular}

${ }^{1}$ Note: some guidelines appear several times as they refer to several elements of the work system.

\begin{tabular}{|c|c|c|c|}
\hline No & $\begin{array}{c}\text { Related to } \\
\text { (leading) nurse }\end{array}$ & Design principle & Reasons and remarks \\
\hline 7 & Basic suggestions & Avoid prolonged asymmetrical postures. & $\begin{array}{l}\text { The asymmetry of } \mathrm{T} \& \mathrm{P} \text { causes higher } \\
\text { pressure and shear forces on the disc. }\end{array}$ \\
\hline 8 & & $\begin{array}{l}\text { Temporary special postures of the caregiver } \\
\text { (squatting, kneeling, standing strongly bent) in } \\
\text { the sense of a change of load are permissible. }\end{array}$ & $\begin{array}{c}\text { The spine "lives on movement". It is not } \\
\text { desirable to adopt a single posture over a } \\
\text { long period of time. }\end{array}$ \\
\hline 9 & Postures & & \\
\hline 10 & & Avoid strong prevention of the nurse at $\mathrm{T} \& \mathrm{P}$. & $\begin{array}{c}\text { Due to the large inclination of the upper } \\
\text { body of the patient in T \& } \mathrm{P} \text {, high pressure } \\
\text { forces are generated on the intervertebral } \\
\text { disc. }\end{array}$ \\
\hline 11 & & Assume a stable posture at $\mathrm{T} \& \mathrm{P}$. & $\begin{array}{c}\text { The safer the caregiver can control } \\
\text { posture and movement, the lower the risk } \\
\text { of accidents and injuries for patient and } \\
\text { caregiver. }\end{array}$ \\
\hline 12 & & $\begin{array}{l}\text { Increase posture stability and improve the use of } \\
\text { force in T \& P by Step and incline positions. }\end{array}$ & $\begin{array}{c}\text { Step and incline positions facilitate weight } \\
\text { shifts of the caregiver. With weight shifts, } \\
\text { movements of the pelvis can be better } \\
\text { triggered. }\end{array}$ \\
\hline 13 & & $\begin{array}{l}\text { Avoid pulling the shoulders up when using force } \\
\text { [23] }\end{array}$ & $\begin{array}{l}\text { Pulling the shoulders up can cause } \\
\text { complaints in the shoulder/neck area. }\end{array}$ \\
\hline 14 & & $\begin{array}{l}\text { Reduce strong lateral inclination of the caregiver } \\
\text { by raising the headboard of the care bed. }\end{array}$ & $\begin{array}{l}\text { The lateral inclination at } \mathrm{T} \& \mathrm{P} \text { causes } \\
\text { higher pressure and shearing forces on } \\
\text { the intervertebral disc. } \\
\text { Caution: Can also have negative effects: } \\
\text { Patient can slide down. }\end{array}$ \\
\hline
\end{tabular}




\begin{tabular}{|c|c|c|c|}
\hline 15 & Action forces & Do not work from "the back". & $\begin{array}{c}\text { The application of force via the back } \\
\text { muscles is strenuous and can lead to } \\
\text { complaints or injuries. The leg muscles } \\
\text { of the caregiver are stronger and better } \\
\text { suited for the application of force. } \\
\text { The motto is "Prefer leg motor skills over } \\
\text { trunk motor skills". }\end{array}$ \\
\hline 17 & Clothing and shoes & $\begin{array}{c}\text { Eliminate the risk of injury by wearing the } \\
\text { correct clothing and footwear. }\end{array}$ & $\begin{array}{c}\text { If the gown is not closed at the back, this } \\
\text { can cause the nurse to get stuck and fall. } \\
\text { Not closed shoes are a hygiene problem } \\
\text { and can also be a cause of falls. }\end{array}$ \\
\hline
\end{tabular}

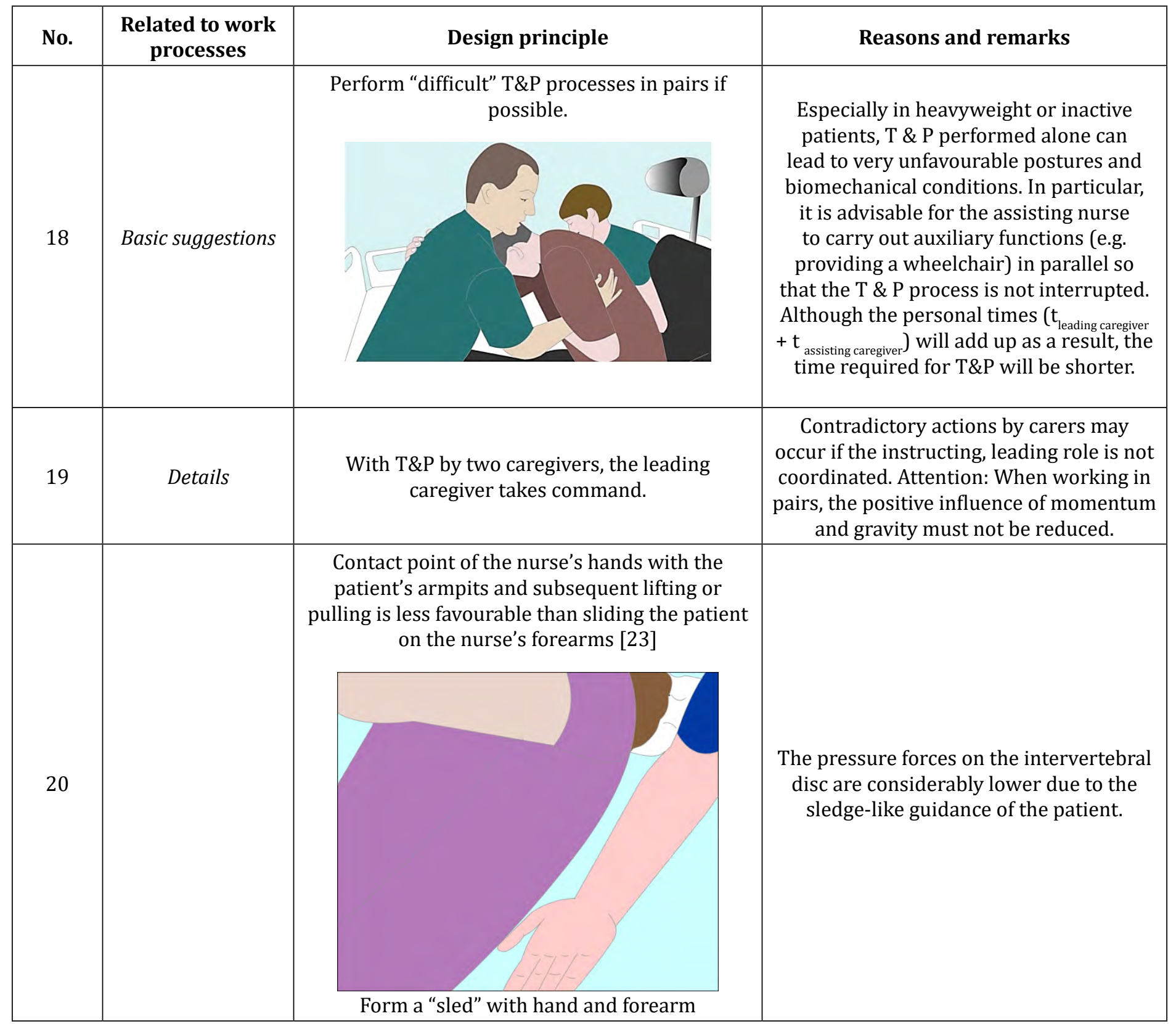




\begin{tabular}{|c|c|c|}
\hline 21 & Avoid spatial confinement. & $\begin{array}{l}\text { Unused work equipment hinders T \& P } \\
\text { processes. They can lead to the caregiver's } \\
\text { falling or even to injuries to the patient. } \\
\text { Therefore, when preparing T\&P, push } \\
\text { these work aids aside or out of the care } \\
\text { room. }\end{array}$ \\
\hline 22 & $\begin{array}{c}\text { Using leverage in the interaction between nurse } \\
\text { and patient. }\end{array}$ & $\begin{array}{l}\text { Stress effects on the skeleton, spine and } \\
\text { musculature are thus reduced.. }\end{array}$ \\
\hline 23 & $\begin{array}{l}\text { In the preparation phase of a transfer, prepare } \\
\text { the work equipment required later. }\end{array}$ & $\begin{array}{l}\text { So that a transfer is not interrupted, } \\
\text { the work equipment required later } \\
\text { must already be prepared. This applies, } \\
\text { for example, to the provision of the } \\
\text { wheelchair at the appropriate location. }\end{array}$ \\
\hline
\end{tabular}

\begin{tabular}{|c|c|c|c|}
\hline No. & Related to work equipment and aids & Design principle & Reasons and remarks \\
\hline 24 & Basic suggestions & $\begin{array}{l}\text { Use height gradients and } \\
\text { inclined planes. }\end{array}$ & $\begin{array}{l}\text { The use of gravity reduces the } \\
\text { amount of effort required by the } \\
\text { nursing staff. }\end{array}$ \\
\hline & $\sqrt{8}$ & $\begin{array}{l}\text { For all positioning and } \\
\text { transfer measures, adjust } \\
\text { the bed height in advance } \\
\text { to the type of measure and } \\
\text { the height of the caregiver. }\end{array}$ & $\begin{array}{l}\text { Torso bending, lateral inclination } \\
\text { and torso twisting are thereby } \\
\text { reduced. }\end{array}$ \\
\hline 25 & Details & $\begin{array}{l}\text { Reduce friction between } \\
\text { patient's body and } \\
\text { mattress or underlay [21]. }\end{array}$ & $\begin{array}{c}\text { The pressure forces on } \\
\text { the intervertebral disc are } \\
\text { considerably lower due to the } \\
\text { sledge-like guidance of the patient. }\end{array}$ \\
\hline 26 & & $\begin{array}{l}\text { Raise the headboard of } \\
\text { bed in preparation for a } \mathrm{T} \\
\text { in order to reduce a strong } \\
\text { lateral inclination of the } \\
\text { caregiver. }\end{array}$ & $\begin{array}{l}\text { The lateral inclination during } \\
\text { transfers causes higher pressure } \\
\text { and shear forces on the } \\
\text { intervertebral disc. }\end{array}$ \\
\hline 27 & & $\begin{array}{l}\text { Do not perform T \& P on } \\
\text { the patient in bed over } \\
\text { "obstacles" (for example } \\
\text { wheelchair). }\end{array}$ & $\begin{array}{l}\text { Otherwise, large lever arms } \\
\text { are created which considerably } \\
\text { increase the pressure and shear } \\
\text { forces on the intervertebral disc. } \\
\text { Therefore "obstacles" should be } \\
\text { cleared away before. }\end{array}$ \\
\hline
\end{tabular}




\begin{tabular}{|c|c|c|}
\hline 28 & $\begin{array}{l}\text { Extension of the arms by } \\
\text { sheets. }\end{array}$ & $\begin{array}{c}\text { By grasping the sheet and not } \\
\text { directly on the patient's body, } \\
\text { both arms of the nurse can remain } \\
\text { stretched } \\
\text { and during the transfer the back is } \\
\text { kept straight so that the } \\
\text { spinal column load takes place } \\
\text { axially and thus physiologically. }\end{array}$ \\
\hline 29 & $\begin{array}{c}\text { For transfers "lying - lying" } \\
\text { adjust both beds or bed } \\
\text { and shower couch to the } \\
\text { same height. }\end{array}$ & $\begin{array}{c}\text { By avoiding a difference in height, } \\
\text { transfer is easier to handle. } \\
\text { Unproductive lifting work of the } \\
\text { patient is eliminated. }\end{array}$ \\
\hline
\end{tabular}

Table 4: Guidelines on improvement of (bio-)mechanical working conditions [24].

\section{References}

1. Raine S, Meadows L, Lynch-Ellerington M (2009) Bobath Concept: Theory and Clinical Practice in Neurological Rehabilitation. Hoboken, Wiley-Blackwell, US.

2. Fringer A, Huth M, Hantikainen V (2014) Nurses' experiences with the implementation of the Kinaesthetics movement competence training into elderly nursing care: a qualitative focus group study. Scandinavian Journal of Caring Sciences 28(4): 757-766.

3. Estryn-Behar M, van der Heijden B, Fry C, Hasselhorn HM (2010) Longitudinal analysis of personal and workrelated factors associated with turnover among nurses. Nursing research 59(3): 166-177.

4. Serranheira F, Cotrim T, Rodrigues V, Nunes C, SousaUva A (2012) Nurses' working tasks and MSDs back symptoms: results from a national survey. Work 41(S1): 2449-2451.

5. Dawson AP, McLennan SN, Schiller SD, Jull GA, Hodges PW, et al. (2007) Interventions to prevent back pain and back injury in nurses: a systematic review. Occup Environ Med 64(10): 642-650.

6. Ellapen TJ, Narsigan S (2014) Work related musculoskeletal disorders among nurses: Systematic Review J Ergonomics S4:003.

7. Cohen MH, Nelson GG, Green DA, Leib R, Matz MW, Et al. (2010) Patient handling and movement assessments: A white paper. Dallas (U.S.) The Facility Guidelines Institute, Dallas, USA.

8. Knibbe J, Friele R (1999) The use of logs to assess exposure to manual handling of patients, illustrated in an intervention study in care home nursing. Int J Industr Ergonomics 24(4): 445-454.
9. Lu JL (2007) Multiple interactions of hazard exposures, role stressors and situational factors, and burnout among nurses. International journal of occupational safety and ergonomics 13(1): 73-82.

10. Marschall J, Hildebrandt S, Nolting HD (2019) DAKGesundheitsreport 2019. DAK Forschung, Hamburg,

11. Bundesministerium für Arbeit und Soziales (2006) Merkblatt zu der Berufskrankheit Nr, 2108. Bundesarbeitsblatt.

12. Van Hoof W, O'Sullivan K, O'Keeffe M, Verschueren S, O'Sullivan P, et al. (2018) The efficacy of interventions for low back pain in nurses: A systematic review. Int J Nursing Studies 77: 222-231.

13. Jacobs M, Weißert Horn M, Diaz Meyer M, Landau K (2018) Physical training to improve transfer techniques and strengthen the musculoskeletal system of nurses caring for chronically sick patients. J Ergonomics 8: 3.

14. Hignett S, McAtamney L (2000) Rapid entire body assessment (REBA). Appl Ergon 31(2): 201-205.

15. Landau K (2020) Pflege gestalten. Ergonomia, Griesheim, Germany.

16. Fallentin N, Viikari-Juntura E, Waersted M, Kilbom A (2001) Evaluation of physical workload standards and guidelines from a Nordic perspective. Scan J Work environ Health 27(S2): 1-52.

17. Landau K, Weissert-Horn M, Jacobs M, Diaz Meyer M (2014) Musculo-skeletal stress when transferring totally dependent patients. J Ergonomics S4: 009.

18. Landau K, Weißert-Horn M, Diaz Meyer M, Jacobs M, Salmanzadeh H, et al. (2019) Workload analysis and ergonomic design of nursing tasks when caring for chronically sick patients. Ergonomics International J 


\section{3(2): 1-11.}

19. Landau K, Diaz-Meyer M, Weißert-Horn M, Jacobs M, Stern H, et al. (2014) Zur Belastung und Beanspruchung beim Patiententransfer von Schwerstpflegebedürftigen. ASU Arbeitsmed. Sozial med. Umweltmedizin 49(11): 850-861.

20. (2018) Center for Ergonomics: 3D Static Strength Prediction Program, Version 7.0.4, University of Michigan.

21. McGill SM, Kavcic NS (2007) Transfer of the horizontal patient: The effect of a friction reducing assistive device on low back mechanics. Ergonomics 48(8): 915-929.

22. Rohmert W (1986) Ergonomics: Concept of work, stress and strain. Appl Psychology 35(2): 159-181.

23. Jäger M, Jordan C, Kuhn S, Beck B, Nienhaus A (2015) Ableitung tätigkeitsspezifischer biomechanisch begründeter Handlungsanleitungen für rückengerechtes Bewegen von Patienten. ASU - Arbeitsmedizin, Sozialmedizin, Umweltmedizin 10: 738-749.

24. Karhula K, Rönnholm T, Sjöngen T (2009) A method for evaluating the load of patient transfers. Occupation Safety and Health Administration. 